\title{
Social work for sociologists: Theory and practice
}

\author{
Kate van Heugten and Anita Gibbs (Eds), 2015 \\ Palgrave Macmillan, New York, NY, USA. \\ ISBN 978-1-137-39296-1, pp. 193, Hardcover, NZD125.00
}

$\mathrm{T}$ he title of this excellent book intrigued me: "Social work for sociologists", rather than "sociology for social work". Good texts on the contribution of sociology are offered by several authors (see for example DunkWest and Verity (2014) and Cree's second edition (Cree, 2010). The different direction of the contribution of ideas, from social work to sociology, suggested in the title of Kate van Heugten and Anita Gibbs' book was creative and offered an opportunity to see how social work authors would engage in such a challenging assignment.

As an enthusiastic sociological social worker, I was very happy to have the opportunity to read this book and see how it met its aim which according to the editors is to introduce students and practitioners of sociology to "some important concepts from social work, concepts of which these readers may be unaware, to their detriment" (p. 1). In the introduction, van Heugten and Gibbs spend some time outlining the conflict that can come between social workers and sociologists with the former being stereotyped as value laden ideologues and the latter as impractical and dry.

Here, I must declare my biases. I can't imagine how one could be a social worker without applying a sociological lens. Social workers with no wish or ability to look beyond the individuals they work with may well be missing a significant professional faculty. To ignore the social, economic, gender and cultural dimensions which structure much of the world in which we live and practice seems to risk blinkered practice and a potentially toxic individualisation of the people with whom we work. And in Aotearoa New Zealand currently that is a significant risk for social work as it faces challenges from social policies that are dominated by neoliberal discourses of surveillance and manipulation of vulnerable citizens (Hyslop, 2016). Only constant critical analysis can prevent us from capture by the blame and shame brigades who are shaping welfare reform.

Conversely, I can't imagine a sociology that doesn't engage in at least thinking about potential solutions to the social problems it explicates or the societal implications of its theorising. While I appreciate a good theory, what lifts theory up into the loftier realms of practice is the recognition that the framework delivers insights that help us do our work. For me, Bourdieu's oft quoted observation that social work "is shot through with the contradictions of the State" (1999, p. 194) delivers a powerful punch when accompanied by his analysis of his conversations with the street level worker who manages the tensions and uncertainties of a marginal occupation. We could be depressed by his analysis or we can grasp it and use it to be strategic and pragmatic.

So, the brief the editors set themselves was admirable and challenging. The book is divided into two sections. The first includes three chapters written by the editors to set the context, the historical roots of social work and sociology as 
linked disciplines, an exploration of key frameworks and a chapter describing the values, ethics and skills of social work practice. The second section comprises six chapters which illustrate the application of social work concepts in various fields.

Social work and sociology have been linked closely for over a century; and in the first chapter, van Heugten and Gibbs provide an overview of this history. The two disciplines have often been co-located in academic departments and this coexistence has not always been comfortable. Social work is frequently seen as the messier and less intellectual discipline. Gender has played a big part in this and from the 1930s to the present day women's achievements may be sidelined in the "department" as women are more visible in the teaching and research of practice than in theoretical scholarship. Van Heugten and Gibbs describe the undervaluing of the scholarship of brilliant women sociologists at the University of Chicago whose activism challenged the narrow gaze of the men. This chapter is a useful overview of these complex interdisciplinary relationships.

What is surprising in a book where all the authors except one have lived in Aotearoa New Zealand is the absence of an in-depth account of the local relationships between sociology and social work. This gap has been recently been filled by Harington's (2016) rich account of the intertwined history of the two disciplines.

The second chapter provides a discussion of the frameworks which underpin social work. Gibbs and van Heugten here define frameworks as encompassing "theory, perspectives, knowledge, values, ethics and critical concepts" (p. 28). The chapter focusses on the praxis of knowledge and action, using a case study to illustrate their approach. The discussion of critical reflection, for example, explains how the sociological concept of reflexivity combined in practice with the pedagogical idea of reflection-in-action in which both theory and practice can change as each informs the other. Narrative, strengthsbased, empowerment and anti-oppressive approaches, and indigenous frameworks are also explored, at each point returning to the case study to demonstrate the praxis. Educators will find this chapter useful for students in integrated theory and practice courses.

Chapter 3 examines the interplay of ethics and values of social work and explores the skills required to embody these in practice. The case study again provided a useful illustrative device. These three chapters taken together create a good foregrounding for the chapters which follow. Each chapter ends with a set of reflective questions. An interesting question posed to sociology readers is about use of self: "to what extent and how is the idea of 'the use of self' relevant to sociologists in their place of study or employment?"

The second section of the book included six chapters which illustrate the application of social work frameworks to practice. While all the content is interesting, the chapters by Keddell and Stanley about risk in work with children and families, Eketone and Walker on bicultural practice, and Tolich on a sociological research internship stood out for me.

Emily Keddell and Tony Stanley have provided a chapter that offers an excellent overview of the contrasting orientations of child welfare and child protection within societies obsessed with the measurement of risk. With reference to highly relevant work on the risk society by scholars such as Beck, Rose and others they explore how risk saturated approaches to practice with children can demonise parents, render invisible the impacts of structural inequalities and intensify the individualisation of social problems that is so prevalent under neoliberalism. These features are contrasted with the social work frameworks that, rather than focus on deficit thinking, instead focus on safety and the 
acknowledgment and nurturing of strengths. They argue that the humanistic approach to families builds partnerships in contrast to the risk averse forensic approaches promoted in actuarial models, so visible in the narrow tools of predictive risk modelling (for further discussion, see Keddell, 2015; de Haan \& Connolly, 2014).

Anaru Eketone and Shayne Walker call for bicultural practice that extends beyond mere tokenism. This chapter commences with a very useful section that looks to define biculturalism and explores the relationships and practices relevant to both sociology and social work. The second part of this excellent chapter addresses the practice(s) of biculturalism. Refreshingly, Eketone and Walker call for an ally model of working together for sociologists and social services workers: "becoming an ally is a form of critical consciousness raising ... that has a transformative outcome" (pp. 115-116). This is an excellent chapter to add to readings in social work courses.

In Chapter 9, Martin Tolich describes the experience of a sociology course in which students in an undergraduate degree experience a work-based learning experience in and internship in organisations. The relevance of that reflective question about use-of-self in Chapter 3 is clearly illustrated in the accounts of student emotions as they encountered relationship issues, anxieties, teamwork dynamics and other challenges well understood by social work students on their first placement.
I enjoyed reading this book very much and will draw on its contents in my own teaching and research. Its value is found in the way the editors and authors bring together insights from social work and sociology and the space created for readers to think about applications. No book of this kind can cover everything but I did feel there was a place for a chapter on community development as nowhere do the ideas and principles of social work and an engaged public sociology coalesce as clearly. Perhaps an idea for the second edition. That gap aside, I would recommend this book for libraries and for personal use by sociological social workers without hesitation.

\section{References}

Bourdieu, P. (1999). The 'abdication of the State and 'an impossible mission. In P. Bourdieu, A. Accardo, et al. (Eds. \& Trans. P. Parkhurst-Ferguson), The weight of the world: Social suffering in contemporary society (pp. 181-202). Palo Alto, CA: Stanford University Press.

Cree, V. E. (2010). Sociology for social workers and probation officers, 2nd ed. New York, NY; London, United Kingdom: Routledge.

de Haan, I., \& Connolly, M. (2014). Another Pandora's box? Some pros and cons of predictive risk modeling. Children and Youth Services Review, 47, 86-91. doi:10.1016/j.childyouth.2014.07.016

Dunk-West, P., \& Verity, F. (2014). Sociological social work. Farnham, UK: Ashgate.

Harington, P. (2016). Sociology and social work in New Zealand. New Zealand Sociology, 31(3), 110-145.

Hyslop, I. K. (2016). Where to social work in a brave new neoliberal Aotearoa? Aotearoa New Zealand Social Work, 28(1), 5-12. doi:10.11157/anzswj-vol28iss1id111

Keddell, E. (2015). The ethics of predictive risk modelling in the Aotearoa/New Zealand child welfare context: Child abuse prevention or neo-liberal tool? Critical Social Policy, 35(1), 69-88. doi:doi:10.1177/0261018314543224 